\title{
Analisa Pengaruh Arang Kayu Bakau, Arang Tempurung Kelapa Dan Arang Kayu Leban Pada Proses Pack Carburizing Terhadap Kekerasan Baja Karbon St 37
}

\author{
Sabri Mazuli ${ }^{1 *}$, Bambang Dwi Haripriadi ${ }^{2 * *}$ \\ 1,2, Jurusan Teknik Mesin, Politeknik Negeri Bengkalis Riau \\ Email :*sabri05mazuli@gmail.com ** bambang@polbeng.ac.id
}

\begin{abstract}
This research was conducted to determine the effect of variations in activated charcoal media and temperature variations on the price of rockwell hardness and the chemical composition of ST 37 steel in the carburizing process. The carburizing process is widely used to increase hardness and add carbon to steel which has a low hardness value and needs to be given special treatment to increase the hardness of the steel. In this study, the carburizing media used were mangrove charcoal, coconut shell charcoal, lebanese wood charcoal that had been made into powder and a mixture of $\mathrm{BaCO} 3$ as a catalyst. In this study, the carburizing process was carried out with temperature variations, namely $750^{\circ} \mathrm{C}, 850^{\circ} \mathrm{C}$ and $900^{\circ} \mathrm{C}$ after reaching the desired temperature and then held with a holding time of 2 hours. The percentage of carbon absorption is more absorbed in lebanese charcoal at a temperature of $900^{\circ} \mathrm{C}$ with the addition of carbon by $0.61 \%$. Whereas for rockwell hardness testing the highest hardness value at $9000 \mathrm{C}$ was found in lebanese charcoal with a hardness value of 79.9 HRC.
\end{abstract}

Keywords: Carburizing, ST 37 Steel, Rockwell Hardness, Chemical Composition.

\section{PENDAHULUAN}

Pemakaian logam ferrous baik baja maupun besi cor dengan karakteristik dan sifat yang berbeda membutuhkan adanya suatu penanganan yang tepat sehingga implementasi dari penggunaan logam tersebut dapat sesuai dengan kebutuhan yang ada. Penggunaan baja karbon rendah banyak digunakan lebih disebabkan karena baja karbon rendah memiliki keuletan tinggi dan mudah dilakukan proses pemesinan karena nilai kekerasannya rendah dan ketahanan ausanya rendah. Baja ini tidak dapat dikeraskan secara kovensional karena memiliki kadar karbon yang rendah sehingga dilakukan proses carburizing.

Proses carburizing adalah proses perlakuan panas dimana besi atau baja menyerap karbon sementara logam dipanaskan dengan adanya bahan yang mengandung karbon, seperti arang atau karbon monoksida. Tujuan dari proses ini adalah untuk meningkatkan kekerasan permukaan namun pada bagian dalam tetap ulet. Penggunaan baja karbon rendah banyak di jual di pasaran ada yang berbentuk lembaran, batangan dan lain-lain.

Baja karbon rendah (ST 37) memiliki kandungan karbon kurang dari 0,3\%. Baja ini sering dipakai untuk kontruksi-kontruksi mesin yang saling bergesekan seperti roda gigi, poros dan lainlain. Namun kekerasan permukaan dari baja tersebut tergolong rendah sehingga sebelum digunakan untuk kontruksi-kontruksi yang disebutkan diatas, maka perlu dimodifikasi atau diberikan perakuaan khusus untuk meningkatkan kekerasan pada permukaannya. Baja karbon tersebut tidak dapat dikeraskan secara konvensional tetapi melalui penambahan unsur karbon dengan proses pack carburizing. Baja karbon rendah (ST 37) mempunyai kekuantan tarik $37-45 \mathrm{Kg} / \mathrm{mm}^{2}$ dan kadar karbonnya $0,16 \%$.

Karbon merupakan salah satu unsur terpenting karena dapat meningkatkan kekerasan dan kekuatan baja. Kandungan karbon didalam struktur baja akan berpengaruh terhadap sifat mampu keras. Sifat ini dibutuhkan untuk komponen mesin yang saling bergesekan atau karena fungsinya harus mempunyai kekerasan tertentu. Kekerasan komponen mesin yang terbuat dari baja, dapat 
diperoleh melalui proses perlakuan panas. Baja dengan kadar karbon rendah sulit untuk dikeraskan (Amstead, B.H. dkk, 1995), tetapi melalui proses penambahan karbon dengan arang aktif kekerasan dapat ditingkatkan.

Menurut Aris Susanto (2018) melakukan penelitian Pengaruh Variasi Suhu Heat Treatment Dengan Media Quenching Oli Terhadap Sifat Mekanik Pada Baja S45C. Waktu tahan yang digunakan selama proses pengarbonan 30 menit dengan variabel suhu yaitu $800^{\circ}, 850^{\circ}$ dan $900^{\circ}$. Hasil atau karakteristik sampel tertinggi material pada pengujian rockwell penekanan intan skala $\mathrm{C}$ terdapat nilai kekerasan yang tertinggi pada suhu $900^{\circ}$ yaitu $21,67 H R C$. semakin tinggi variasi suhu yang diberikan maka akan semakin keras.

Dengan banyaknya penggunaan baja karbon untuk itu perlu diberikan perlakuaan khusus untuk meningkatkan kualitasnya, seperti kekuatan dan kekerasan. Untuk meningkatkan mutu permukaan baik dari sisi tampilan (deformasi), ketahanan terhadap korosi maupun kekerasannya maka logam harus dilapisi dengan unsur lain yang dapat memberikan sifat-sifat yang diinginkan. Pada dasarnya proses pelapisan baja karbon yaitu proses pengerasan permukaan dengan merubah atau menambah komposisi unsur kimia baja karbon. [11]

Berdasarkan uraian diatas, hal ini membuat penulis tertarik untuk memberikan perlakuan panas menggunakan arang aktif yaitu dengan judul penelitian "Analisa Pengaruh Arang Kayu Bakau, Arang Tempurung Kelapa Dan Arang Kayu Leban Pada Proses Pack Carburizing Terhadap Kekerasan Baja Karbon St 37”. Sehingga dengan dilakukan penelitian ini mungkin dapat menambah nilai kekerasan yang tertinggi. Dalam proses pengarbonan sumber karbon yang digunakan adalah serbuk arang kayu bakau, arang tempurung kelapa dan arang kayu leban dan dengan variasi temperatur yaitu $750^{\circ} \mathrm{C}, 850^{\circ} \mathrm{C}$ dan $900^{\circ} \mathrm{C}$, temperatur yang digunakan pada penelitian ini untuk mengetahui nilai kekerasan yang tertinggi akibat variasi arang aktif terhadap proses pack carburizing baja karbon ST 37. Adapun tujuan penelitian ini untuk mengetahui nilai kekerasan baja ST 37 pada proses carburizing dan Untuk mengetahui persentase karbon yang masuk akibat variasi serbuk arang aktif dan variasi temperatur pada proses pack carburizing dengan melakukan pengujian komposisi kimia.

\section{LANDASAN TEORI}

\section{Pengerasan Permukaan Baja ( Steel Surface Hardening )}

Pengerasan permukaan dilakukan dengan 2 cara yaitu seluruh permukaan dikeraskan atau sebagian saja dari permukaan yang dikeraskan.Tujuan pengerasan permukaan secara umum adalah memperbaiki ketahanan aus. Pengerasan permukaan pada baja meliputi dua jenis yaitu induction hardening dan thermo chemical treatment. Prinsip kerja induction hardening adalah memanaskan permukaan baja hingga temperatur austenit yang sesuai dengan baja yang bersangkutan, kemudian disemprotkan pendingin sehingga permukaan menjadi keras. Prinsip kerja dari thermo chemical treatment adalah menambahkan unsur karbon ke dalam baja untuk mengeraskan bagian permukaan baja tersebut. Salah satu penerapan dari proses thermo chemical treatment adalah carburising (pengarbonan). Thermo chemical treatment dilakukan terhadap baja yang mempunyai kadar karbon di bawah $0,3 \%$. Kadar karbon ini tidak memungkinkan terjadinya fasa martensit yang keras.

\section{Carburizing}

Carburizing adalah suatu proses penambahan unsur karbon pada permukaan suatu komponen secara difusi untuk memperbaiki sifat fisis dan mekanisnya. Proses ini biasanya dilakukan terhadap baja karbon rendah. Sampai saat ini proses karburising masih banyak digunakan, meskipun dengan metode pack karburizing yang sederhana. Metode ini terdiri dari dua proses perlakuan terhadap komponen, yaitu: (a) perlakuan termokimia yang mengubah komposisi kimia permukaan baja dengan difusi karbon dan/atau nitrogen dan terkadang elemen lainnya dan (b) transformasi fasa akibat pemanasan dan pendinginan cepat pada permukaan luar.

Pada metode pack karburizing, komponen yang akan dikarburasi ditempatkan dalam kotak berisi media penambah unsur karbon (media karburasi). Bahan-bahan alam dan limbah dapat 
dimanfaatkan sebagai media karburasi, seperti: arang kayu arang tempurung kelapa, arang batu baterai bekas, arang pohon bakau dan arang sekam padi. Nurjito dan Arianto Leman S (2003).

Karbon aktif adalah karbon yang di proses sedemikian rupa sehingga pori - porinya terbuka, dan dengan demikian akan mempunyai daya serap yang tinggi. Karbon aktif merupakkan karbon yang bebas serta memiliki permukaan dalam (internal surface), sehingga mempunyai daya serap yang baik. Keaktifan daya menyerap dari karbon aktif ini tergantung dari jumlah senyawa kabonnya yang berkisar antara $85 \%$ sampai $95 \%$ karbon bebas. Karbon aktif yang berwarna hitam, tidak berbau, tidak terasa dan mempunyai daya serap yang jauh lebih besar dibandingkan dengan kabon aktif yang belum menjalani proses aktivasi, serta mempunyai permukaan yang luas, yaitu memiliki luas antara 300 sampai $2000 \mathrm{~m} / \mathrm{gram}$. Karbon aktif ini mempunyai dua bentuk sesuai ukuran butirannya, yaitu karbon aktif bubuk dan karbon aktif granular (butiran).

Karbon aktif merupakan suatu bentuk arang yang telah melalui aktifasi dengan menggunakan gas $\mathrm{CO} 2$, uap air atau bahan-bahan kimia sehingga pori-porinya terbuka dan dengan demikian daya absorpsinya menjadi lebih tinggi terhadap zat warna dan bau. Karbon aktif mengandung 5 sampai 15 persen air, 2 sampai 3 persen abu dan sisanya terdiri dari karbon. Karbon aktif berbentuk amorf terdiri dari pelat-pelat datar, disusun oleh atom-atom $C$ yang terikat secara kovalen dalam suatu kisi heksagonal datar dengan satu atom $C$ pada setiap sudutnya. Pelat-pelat tersebut bertumpuk-tumpuk satu sama lain membentuk kristal-kristal dengan sisa hidrokarbon dan senyawa organik lain yang tertinggal pada permukaannya. Bahan baku karbon aktif dapat berasal dari bahan nabati atau turunannya dan bahan hewani. Mutu karbon aktif yang dihasilkan dari tempurung kelapa mempunyai daya serap tinggi, karena arang ini berpori- pori dengan diameter yang kecil, sehingga mempunyai internal yang luas. Luas permukaan arang adalah $2 \times 104 \mathrm{~cm}^{2}$ per gram, tetapi sesudah pengaktifan dengan bahan kimia mempunyai luas sebesar 5 x 106 sampai $15 \mathrm{x}$ $107 \mathrm{~cm}^{2}$ per gram . Ada 2 tahap utama proses pembuatan karbon aktif yakni proses karbonasi dan proses aktifasi. Dijelaskan bahwa secara umum proses karbonisasi sempurna adalah pemanasan bahan baku tanpa adanya udara sampai temperatur yang cukup tinggi untuk mengeringkan dan menguapkan senyawa dalam karbon. Pada proses ini terjadi dekomposisi termal dari bahan yang mengandung karbon dan menghilangkan spesies non karbonnya. Proses aktifasi bertujuan untuk meningkatkan volume dan memperbesar diameter pori setelah mengalami proses karbonisasi, dan meningkatkan penyerapan.

1. Karbon aktif dapat di aktifasi dangan 2 (dua) cara, yaitu dengan cara aktifasi kimia dan aktifasi fisika. Aktifasi kimia, arang hasil karbonisasi direndam dalam larutan aktifasi sebelum dipanaskan. Pada proses aktifasi kimia, arang direndam dalam larutan pengaktifasi selama 24 jam lalu ditiriskan dan dipanaskan pada suhu $600-9000^{\circ} \mathrm{C}$ selama 2 jam.

2. Aktifasi fisika, yaitu proses menggunakan gas aktifasi misalnya uap air atau CO2 yang dialirkan pada arang hasil karbonisasi.Proses ini biasanya berlangsung pada temperature $800-$ $11000^{\circ} \mathrm{C}$.

Karbon aktif bersifat sangat aktif dan akan menyerap apa saja yang kontak dengan karbon tersebut. Karbon aktif digunakan untuk menjernihkan air, pemurnian gas, industri minuman, farmasi, katalisator dan berbagai macam penggunaan lain. Selain di bidang pengolahan air, karbon aktif dapat digunakan di berbagai industri seperti pengolahan / tambang emas dengan berbagai ukuran mesh maupun iondine number. Juga digunakan untuk dinding partisi, penyegar kulkas, vas bunga, dan ornamen meja. Di balik legamnya, barang gosong itu ternyata sangat kaya manfaat. Karbon aktif dapat digunakan sebagai bahan pemucat, penyerap gas, penyerap logam, menghilangkan polutan mikro misalnya zat organic maupun anorganik, detergen, bau, senyawa phenol dan lain sebagainya. Pada saringan arang aktif ini terjadi proses adsorpsi, yaitu proses penyerapan zat - zat yang akan dihilangkan oleh permukaan arang aktif, termasuk $\mathrm{CaCo} 3$ yang menyebabkan kesadahan. Apabila seluruh permukaan arang aktif sudah jenuh, atau sudah tidak mampu lagi menyerap maka kualitas air yang disaring sudah tidak baik lagi, sehingga arang aktif harus diganti dengan arang aktif yang baru.

Menurut Miswadi et al (2015 ) panglong arang yang produktif tidak hanya dimiliki oleh masyarakat Akit. Hasil observasi menemukan 20 unit panglong arang, hanya 9 unit yang dikelola

Copyright $^{\circledR} 2020$ Jurnal Rekayasa Material, Manufaktur dan Energi. This is an open acces article under the CC-BY-SA lisence (https://creativecommons.org/licenses/by-sa/4.0/). 
oleh masyarakat. Kondisi ini menunjukkan bahwa produksi arang mangrove tidak hanya karena faktor memberikan kesempatan berusaha bagi masyarakat Akit dalam memanfaatkan sumber daya alam untukmemenuhi kebutuhan ekonomi, tetapi akhirnya cenderung murni karena motivasi ekonomi dan memanfaatkan peluang usaha bagi masyarakat lain yang memiliki kecukupan modal usaha.

Penambahan karbon yang disebut carburizing atau karburasi, dilakukan dengan cara memanaskan pada temperatur yang cukup tinggi yaitu pada temperature austenit dalam lingkungan yang mengandung atom karbon aktif, sehingga atom karbon aktif tersebut akan berdifusi masuk ke dalam permukaan baja dan mencapai kedalaman tertentu. Setelah proses difusi, diikuti perlakuan pendinginan cepat (quenching), sehingga diperoleh permukaan yang lebih keras,tetapi liat dan tangguh bagian tengahnya. Difusi adalah gerak spontan dari atom atau molekul di dalam bahan yang cenderung membentuk komposisi yang seragam. Hukum pertama Fick's menyatakan bahwa difusi dari sebuah elemen dalam suatu bahan substrat merupakan fungsi koefisien difusi dan gradien konsentrasi. Gradien konsentrasi adalah jumlah atom yang terdapat disekitar substrat dibandingkan dengan jumlah atom yang terdapat di dalam substrat. Ada beberapa faktor yang mempengaruhi kecepatan difusi yaitu, temperatur, komposisi dan waktu (Smallman, Bishop, 2000 ). Pendinginan cepat dalam proses carburizing bertujuan untuk memperoleh permukaan yang lebih keras akibat perubahan struktur mikro pada permukaan baja yang telah dikarburasi. Dari bermacam-macam struktur mikro, martensit merupakan yang paling keras dan kuat namun paling getas, Callister, (1994).

Metode proses carburizing dibedakan berdasarkan media karburasinya, yaitu gas, cair dan padat. Pack carburizing adalah metode carburizing yang paling sederhana dibanding metode cair dan gas, karena dapat dilakukan dengan peralatan yang sederhana. Pada metode ini, komponen ditempatkan dalam kotak berisi media karburasi yang saat pemanasan pada suhu austenisasi $(842-$ $953^{\circ} \mathrm{C}$ ) akan mengeluarkan gas $\mathrm{CO} 2$ dan $\mathrm{CO}$. Pembentukan karbon monoksida ditingkatkan oleh energizer atau katalis, seperti barium karbonat (BaCO3), kalsium karbonat (CaCO3), kalium karbonat (K2CO3), dan natrium karbonat (Na2CO3), yang hadir di kompleks karburasi. Kandungan karbon dari setiap jenis arang adalah berbeda-beda. Semakin tinggi kandungan karbon dalam arang, maka penetrasi karbon ke permukaan baja akan semakin baik pula (Y. Lakhtin,1975).

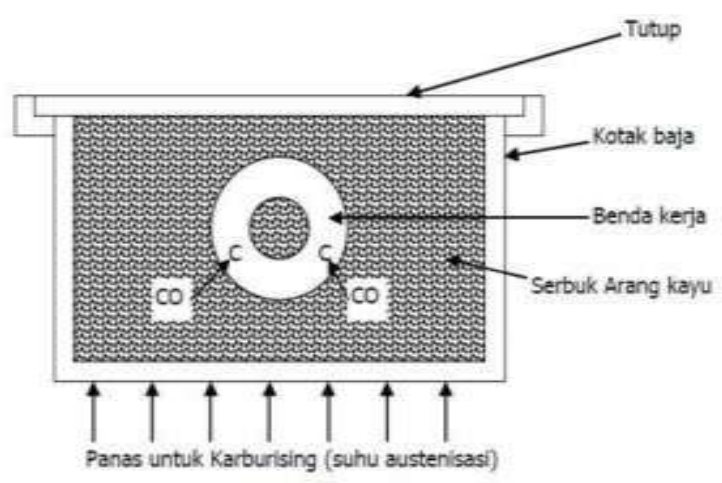

Gambar 1. Proses pack carburizing

Gas $C O$ ini bereaksi dengan permukaan baja karbon rendah membentuk atom karbon yang kemudian terdifusi masuk ke dalam baja mengikuti persamaan:

$2 \mathrm{CO}+\mathrm{Fe} \rightarrow \mathrm{Fe}(\mathrm{C})+\mathrm{CO} 2$ 


\section{METODE PENELITIAN}

Penelitian mengenai pengaruh carburizing terhadap kekerasan baja karbon ST 37, penelitian ini diawali dengan mencari referensi dan literatur. Dari studi literatur ditentukan bahan-bahan yang digunakan. Setelah didapat bahan dan alat yang akan digunakan selanjutnya dilakukan perancangan eksperimen. Pada perancangan eksperimen ini ditentukan jenis variasi temperatur dan variasi arang aktif. Untuk mendapatkan hasil yang diinginkan dilakukan pengukuran dan dicatat dengan proses yang telah ditentukan,kemudian dilakukan pengolahan dan analisa data dari pengaruh perbedaan temperatur dan variasi arang yang digunakan. Proses penelitian ini mengenai pengaruh carburizing terhadap harga kekerasan rockwell dan komposisi kimia pada permukaan baja karbon ST 37. Proses dan langkah-langkah dari penelitian dapat dilihat pada gambar 2. dibawah ini :

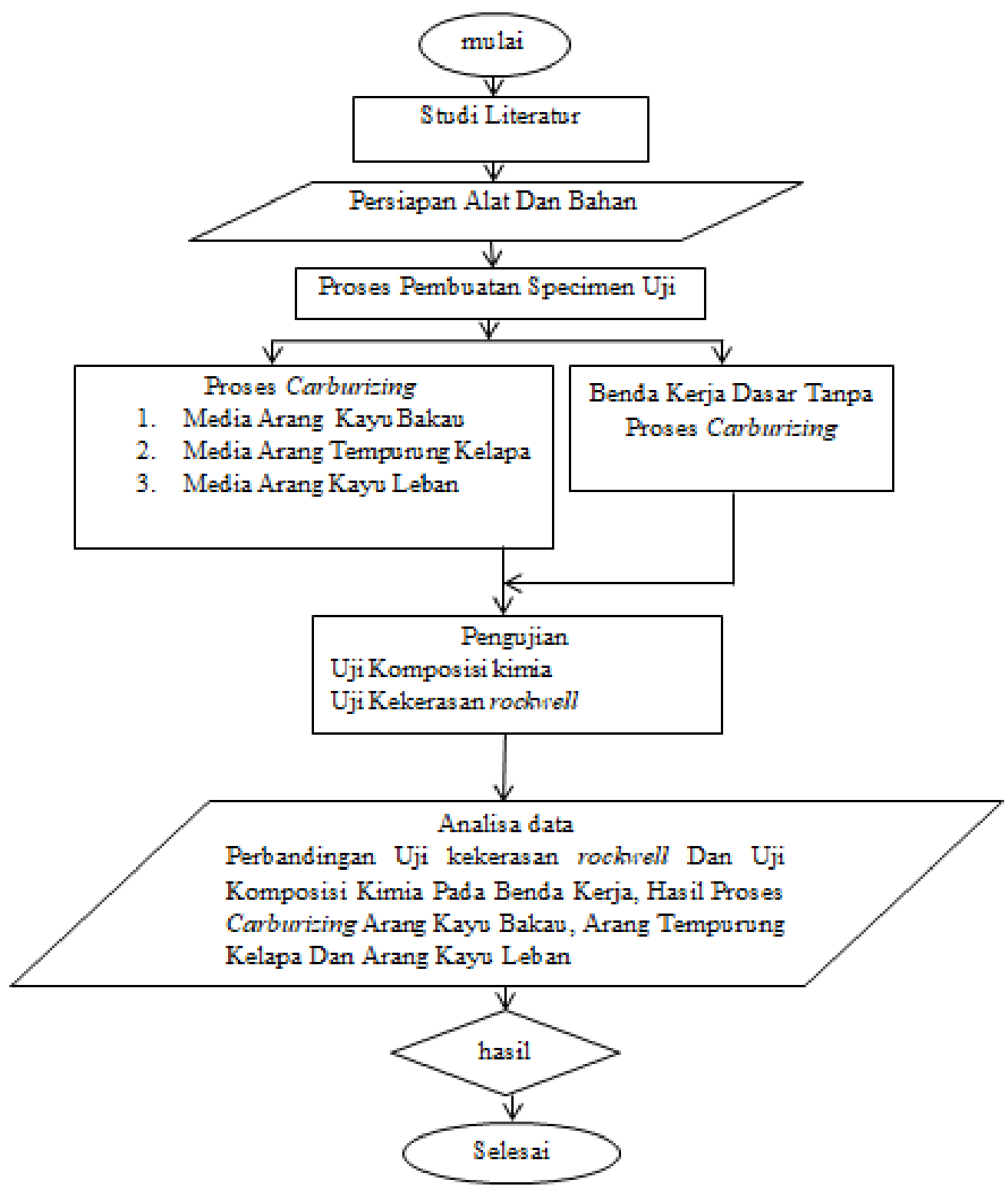

Gambar 2. flowchat penelitian 


\section{HASIL DAN PEMBAHASAN}

\section{Benda Kerja Yang Diteliti}

Pengujian kompisisi kimia dilakukan di PT. Indah kiat Pulp and Paper. Material yang digunakan baja St 37. Untuk memastikan baja tersebut harus dilakukan pengujian komposisi kimia. Dari pengujian menunjukkan bahwa baja tersebut tergolong baja St 37 karena unsur karbon baja kurang dari $0,3 \%$. Komposisi kimia yang terkandung dalam baja tersebut dapat dilihat pada tabel 1. Dibawah :

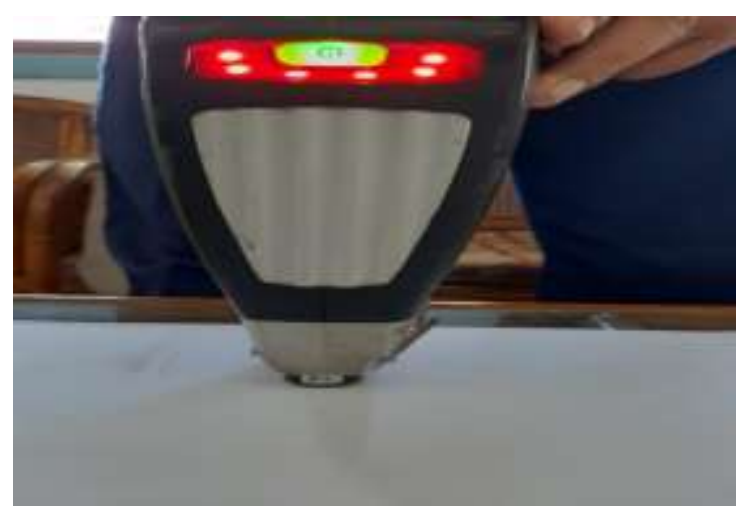

Gambar 3. pengujian komposisi kimia

Tabel 1. Hasil pengujian komposisi kimia

\begin{tabular}{|c|c|c|c|c|c|c|c|}
\hline \multirow{2}{*}{ Spesimen } & \multirow[b]{2}{*}{ Suhu } & \multicolumn{6}{|c|}{ Unsur kimia (\%) } \\
\hline & & $\mathrm{Fe}$ & $C$ & $\mathrm{Cr}$ & $S$ & $M n$ & $P$ \\
\hline Tanpa Carburizing & & 98,94 & 0,12 & 0,10 & 0,3 & 0,15 & 0,1 \\
\hline Arang Kayu Bakau & & 99,16 & 0,23 & 0,30 & 0,4 & 0,20 & 0,1 \\
\hline Arang Tempurung Kelapa & $750^{\circ}$ & 99,25 & 0,63 & 0,35 & 0,6 & 0,28 & 0,1 \\
\hline Arang Kayu Leban & & 99,28 & 0,67 & 0,25 & 0,8 & 0,30 & 0,2 \\
\hline Arang Kayu Bakau & & 99,20 & 0,25 & 0,33 & 0,5 & 0,23 & 0,1 \\
\hline Arang Tempurung Kelapa & $850^{\circ}$ & 99,30 & 0,65 & 0,38 & 0,8 & 0,29 & 0,2 \\
\hline Arang Kayu Leban & & 99,33 & 0,70 & 0,27 & 0,9 & 0,33 & 0,2 \\
\hline Arang Kayu Bakau & & 99,26 & 0,28 & 0,34 & 0,7 & 0,25 & 0,2 \\
\hline Arang Tempurung Kelapa & $900^{\circ}$ & 99,35 & 0,70 & 0,40 & 0,10 & 0,30 & 0,2 \\
\hline Arang Kayu Leban & & 99,36 & 0,73 & 0,28 & 0,12 & 0,36 & 0,3 \\
\hline
\end{tabular}

Dari tabel 1. diatas hasil pengujian komposisi kimia dapat dijelaskan bahwa adapun variasi arang dan variasi temperatur dapat menambah unsur-unsur yang terkandung dalam baja, adapun nilai penambahan bahan karbon yang terbaik untuk pengerasan baja st 37 terdapat pada arang kayu leban dengan suhu $900^{\circ} \mathrm{C}$ dengan kandungan karbon $0,73 \%$ sehingga baja tersebut akan menjadi lebih keras. 
Adapun persentase kenaikan karbon pada spesimen yang telah diberi perlakuan proses carburizing yaitu dapat dilihat pada tabel 2. dibawah ini

Tabel 2. Persentase kenaikan carbon

\begin{tabular}{lccc}
\multicolumn{1}{c}{ Spesimen } & Suhu & Persentase karbon \% & Persentase kenaikan \% \\
\hline Tanpa Carburizing & 0,12 & 0,12 \\
\hline Arang Kayu Bakau & $750^{\circ}$ & 0,23 & 0,11 \\
Arang Tempurung Kelapa & & 0,63 & 0,51 \\
Arang Kayu Leban & 0,67 & 0,55 \\
\hline Arang Kayu Bakau & $850^{\circ}$ & 0,25 & 0,13 \\
Arang Tempurung Kelapa & 0,65 & 0,53 \\
Arang Kayu Leban & & 0,70 & 0,58 \\
\hline Arang Kayu Bakau & $900^{\circ}$ & 0,28 & 0,16 \\
Arang Tempurung Kelapa & & 0,70 & 0,58 \\
Arang Kayu Leban & 0,73 & 0,61 \\
\hline
\end{tabular}

Pada tabel 2. diatas menunjukkan grafik persentase (\%) kenaikan karbon terlihat pada c3 yaitu carburizing menggunakan arang kayu leban dengan suhu $900^{\circ} \mathrm{C}$ terjadi banyaknya penyerapan karbon, dimana kandungan karbon yang terdapat pada spesimen uji merupakan unsur penting untuk mempengaruhi nilai kekerasan pada fase kristal lebih banyak, hal ini disebabkan karena atom-atom karbon pada arang kayu leban lebih banyak terserap dibandingkan arang kayu bakau dan arang tempurung kelapa. Hal ini dipengaruhi oleh potensial karbon yang terkandung dalam arang kayu leban lebih mudah terserap dari pada yang lain.

\section{HASIL PENGUJIAN KEKERASAN ROCWELL DAN ANALISA}

Pengujian kekerasan rockwell dilakukan dengan cara memberikan beban minor $10 \mathrm{kgf}$, beban mayor $140 \mathrm{kgf}$ dan memiliki beban total penekanan sebesar $150 \mathrm{kgf}$. Setelah dilakukan penekanan pada spesimen kemudian ditahan selama 10 detik. Spesimen yang digunakan dengan diameter 20 $\mathrm{mm}$ dan panjang benda kerja yang diteliti $15 \mathrm{~mm}$. Pengujian ini dilakukan setelah spesimen dipanaskan mencapai suhu $750^{\circ} \mathrm{C}, 850^{\circ} \mathrm{C}$ dan $900^{\circ} \mathrm{C}$ kemudian spesimen ditahan hingga mencapai waktu penahanan selama 2 jam kemudian spesimen dikeluarkan dari tungku pemanasan dan dibiarkan dingin dengan sendirinya. Pengujian kekerasan rockwell diambil 10 titik pengujian perspesimen. Dimana 10 titik pengujian tersebut 5 diambil pada tengah-tengah dan 5 di tepi-tepi spesimen uji, tujuan dari pengambilan titik uji untuk mengetahui seberapa besar pengaruh harga kekerasan pada perlakuan carburizing. Adapun nilai rata-rata kekerasan yang diperoleh pada tiap titik-titik pengujian yang dilakukan dapat dilihat pada tabel 4. dan gambar 5. dibawah ini. 


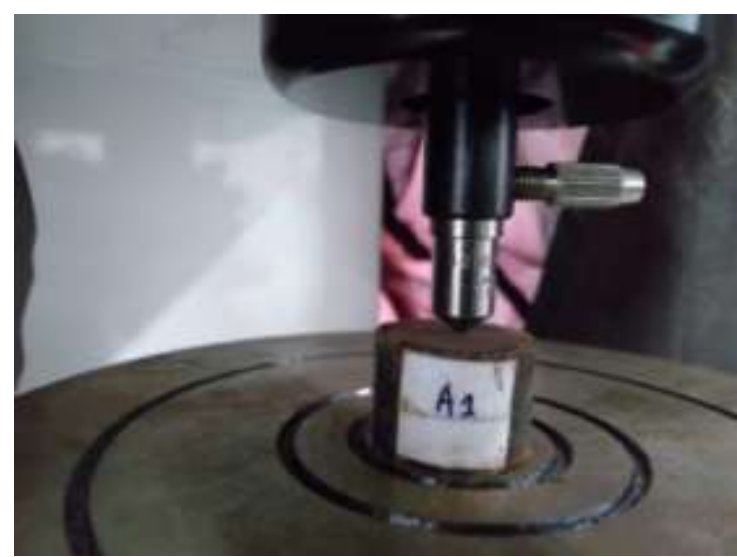

Gambar 4. pembebanan rockwell skala C

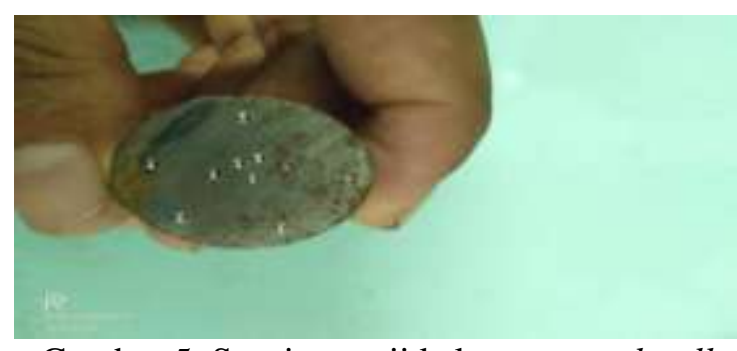

Gambar 5. Spesimen uji kekerasan rockwell

Tabel 3. Rata-rata pengujian rockwell

\begin{tabular}{llcrrrrl}
\hline No & \multicolumn{1}{c}{ Spesimen } & Suhu & $\begin{array}{c}\text { Beban } \\
\text { minor }\end{array}$ & $\begin{array}{c}\text { Beban } \\
\text { mayor }\end{array}$ & $\begin{array}{c}\text { Beban } \\
\text { total }\end{array}$ & $\begin{array}{c}\text { Rata-rata } \\
\text { HRC }\end{array}$ & Warna skala \\
\hline A & Tanpa carburizing & & 10 & 140 & 150 & 57,8 & Hitam \\
\hline a1 & Arang kayu bakau & & 10 & 140 & 150 & 69,4 & Hitam \\
a2 & Arang tempurung kelapa & 750 & 10 & 140 & 150 & 71,4 & Hitam \\
a3 & Arang kayu leban & & 10 & 140 & 150 & 76,2 & Hitam \\
\hline b1 & Arang kayu bakau & & 10 & 140 & 150 & 71,9 & Hitam \\
b2 & Arang tempurung kelapa & 850 & 10 & 140 & 150 & 74,5 & Hitam \\
b3 & Arang kayu leban & & 10 & 140 & 150 & 79 & Hitam \\
\hline c1 & Arang kayu bakau & & 10 & 140 & 150 & 77,6 & Hitam \\
c2 & Arang tempurung kelapa & & 10 & 140 & 150 & 78,1 & Hitam \\
c3 & Arang kayu leban & & 10 & 140 & 150 & 79,7 & Hitam \\
\hline
\end{tabular}

Copyright $^{\circledR} 2020$ Jurnal Rekayasa Material, Manufaktur dan Energi. This is an open acces article under the CC-BY-SA lisence (https://creativecommons.org/licenses/by-sa/4.0/). 


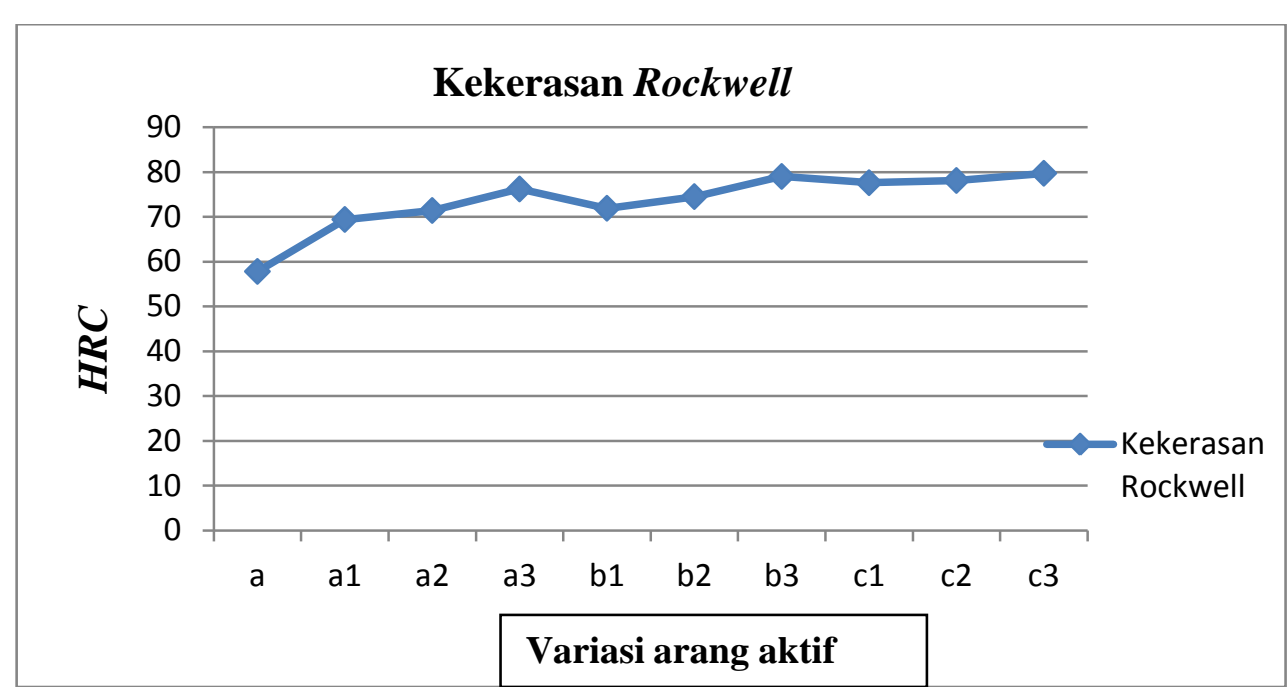

Gambar 6. Grafik rata-rata kekerasan rockwell (HRC)

Pada gambar 6. diperoleh grafik hasil penelitian untuk proses carburizing baja st 37 dengan variasi arang, variasi temperatur dan waktu penahanan masing-masing 2 jam setelah mencapai suhu $750^{\circ} \mathrm{C}, 850^{\circ} \mathrm{C}$ dan $900^{\circ} \mathrm{C}$. Adapun nilai kekerasan baja sebelum carburizing sebesar 57,8 $\mathrm{HRC}$, proses carburizing untuk suhu $750^{\circ} \mathrm{C}$ terdapat nilai kekerasan yg tertinggi pada arang kayu leban dan campuran baco3 (a3) sebesar 76,2 $H R C$, nilai kekerasan arang tempurung kelapa dan campuran baco3 (a2) sebesar 71,4 $\mathrm{HRC}$ dan untuk nilai kekerasan yang terendah pada suhu $750^{\circ} \mathrm{C}$ yaitu carburizing arang kayu bakau dan campuran baco3 (a3) dengan nilai kekerasan 69,4 HRC. Proses carburizing untuk suhu $850^{\circ} \mathrm{C}$ terdapat nilai kekerasan yang tertinggi pada arang kayu leban dan campuran baco3 (b3) sebesar $79 H R C$, nilai kekerasan arang tempurung kelapa dan campuran baco3 (b2) sebesar 74,5 HRC dan untuk nilai kekerasan yang terendah pada suhu $900^{\circ} \mathrm{C}$ yaitu carburizing arang kayu bakau dan campuran baco3 (b1) dengan nilai kekerasan 71,9 HRC. Sedangkan pada proses carburizing untuk suhu $900^{\circ} \mathrm{C}$ terdapat nilai kekerasan yang tertinggi pada arang kayu leban dan campuran baco3 (c3) sebesar 79,7 HRC, nilai kekerasan arang tempurung kelapa dan campuran baco3 (c2) sebesar 78,1 dan nilai kekerasan yang terendah pada suhu $900^{\circ} \mathrm{C}$ yaitu pada proses carburizing arang kayu bakau dan campuran baco3 (c1) dengan nilai kekerasan 77,6 HRC.

Perbedaaan harga kekerasan pada proses carburizing dipengaruhi oleh arang aktif dan temperatur. Sehingga dengan diberinya campuran arang aktif molekul-molekul struktur kristal dari baja akan semakin renggang dan menjadi besar, sehingga nilai kekerasan yang dimiliki dari baja tersebut akan menjadi keras akibat dari arang aktif dan temperatur semakin tinggi temperatur yang digunakan maka baja pun akan semakin keras.

\section{KESIMPULAN}

Dari hasil penelitian dan analisa data yang telah dilakukan, dapat diambil kesimpulan sebagai berikut :

1. Dari hasil pengujian komposisi kimia persentase penyerapan karbon yang lebih banyak terserap pada arang kayu leban dengan suhu $900^{\circ} \mathrm{C}$ dengan penambahan karbon sebesar $0,61 \%$.

2. Pengaruh variasi arang aktif dan variasi suhu pemanasan $750^{\circ} \mathrm{C}, 850^{\circ} \mathrm{C}$ dan $900^{\circ} \mathrm{C}$ dengan waktu penahanan 2 jam, maka diperoleh nilai kekerasan yang terbaik pada suhu $900^{\circ} \mathrm{C}$ proses carburizing arang kayu leban dengan nilai kekerasan rata-rata 79,9 $H R C$. Adapun nilai kekerasan yang terendah pada suhu $750^{\circ} \mathrm{C}$ pada proses carburizing menggunakan arang kayu bakau dengan nilai kekerasan rata-rata 69,4 HRC Selain dari variasi suhu untuk 
menambah nilai kekerasan Sumber arang juga mempengaruhi nilai kekerasan, semakin banyak unsur karbon yag masuk pada spesimen maka nilai kekerasan akan semakin tinggi.

\section{DAFTAR PUSTAKA}

[1] Aras A. S,(2013) "Pengaruh Holding Time Pada Proses Pack karburizing Media Arang Kemiri-Batium Karbonat Terhadap Sifat Mekanis Baja Karbon Rendah". Skripsi Teknik Mesin Universitas Tadulako Palu.

[2] Akay, S.K., Yazika, M., Avinic, A., 2008. The Effect Of Heat Treatment On Phisical Properties Of Low Carbon Steel, Proceeding Of Romanian Academy Series A, Vol 10.

[3] Budinski, K.G., (1999) "Engineering Materials", 6 Th Edition, Prentic-Hall Inc., NEW Jersey.

[4] Darmanto (2006) "Pengaruh Holding Time Terhadap Sifat Kekerasan Dengan Refining The Core Pada Proses Carburizing Material Baja Karbon Rendah", Jurnal Traksi Vol 4, No. 2 Desember 2016.

[5] Djafrie, S.(1985) “Ilmu Dan Teknologi Bahan, Erlangga”, jakarta.

[6] Irfan (2012) "Pengaruh Proses Packarburizing Media Arang Kayu Asam Terhadap Sifat Mekanis Baja Karbon Rendah", Skripsi Teknik Mesin Universitas Tadulako Palu

[7] Hafni (2016) Pengaruh Variasi Komposisi Arang Tempurung Kelapa Dan Proses Pack Carburizing Pada Baja Karbon Rendah Di Tinjau Dari Struktur Mikro, fakultas teknologi industri institut teknologi Padang, Jl. Gajah Mada, KandisNanggalo, Padang

[8] Iqbal, M, (2007) "Pengaruh Packcarburizing Arang Tempurung Kelapa-Barium Carbonat Terhadap Kekerasan Dan Keausan Baja Karbon AISI 1020". Thesis. Universitas Gajah Mada. Yogyakarta.

[9] Masyrukan, Penelitian Sifat Fisis Dan Mekanis Baja Karbon Rendah Akibat Pengaruh Proses Pengarbonan Dari Arang Kayu Jati, Jurusan Teknik Mesin Universitas Muhammadiyah Surakarta, JL.A. Yani Tromol Pos 1 Pabelan Kartasura.

[10] Djaprie, S., 1983, Ilmu Dan Teknologi Bahan, Erlangga, Jakarta.

[11] Murdani (2017) "Analisa Pengaruh Media Carburizing Antara Arang Tempurung Kelapa Dan Arang Kayu Bakau Terhadap Baja Karbon Rendah". Tugas Akhir Program Studi Teknik Mesin, Fakultas Teknik, Universitas Muhammadiyah Riau.

[12] http://pusat-lingkaran.blogspot.com/2017/07/pengujian-kekerasan-bahan-denganmetode.html (13 januari 2020 jam 10.01)

[13] Dr. Supriyono, M. T. Dkk 2012 "Penelitian Sifat Fisis Dan Mekanis Baja Karbonisasi Arang Kayu Sengon" Jurusan Teknik Mesin Fakultas Teknik Universitas Muhammadiyah Surakarta.

[14] Asfarizal ${ }^{1} \&$ Suhardiman $^{2}$ (2012) “Analisa Kekerasan Perlakuan Panas Baja Pegas Dengan Pendingin Sistem Pancaran Pada Tekanan 20, 40 Dan 60 Psi" Dosen Teknik Mesin Institut Teknologi Padang Dan Alumni Teknik Mesin Institit Teknologi Padang.

[15] Yeni Yusuf Tonglolangi (2016) "Analisis Pengaruh Waktu Perlakuan Panas Terhadap Nilai Kekerasan Karburasi Baja Karbon Rendah" Fakultas Teknik,Program Studi Teknik Mesin UKI Toraja.

[16] Sri Anastasia Yudistirani Dkk (2017) “ Analisa Kekerasan Pada Outer Ring Dan Inner Ring Hasil Proses Heat Treatment" Jurusan Teknik Kimia Dan Jurusan Teknik Mesin Fakultas Teknik, Universitas Muhammadiyah Jakarta, Indonesia.

[17] DH Nugroho (2013) eprints. Ums.ac.id, BAB IV Hasil Dan Pembahasan ( 14 Juni 2020 jam 10.00) 